\title{
Pharmacokinetics, safety, and endocrine and appetite effects of ghrelin administration in young healthy subjects
}

Takashi Akamizu ${ }^{1}$, Kazuhiko Takaya ${ }^{1}$, Taiga Irako ${ }^{1}$, Hiroshi Hosoda ${ }^{1}$, Satoshi Teramukai ${ }^{3}$, Akiko Matsuyama ${ }^{3}$, Harue Tada $^{3}$, Kazumi Miura ${ }^{4}$, Akira Shimizu ${ }^{2}$, Masanori Fukushima ${ }^{3}$, Masayuki Yokode ${ }^{4}$, Koichi Tanaka ${ }^{5}$ and Kenji Kangawa ${ }^{1,6}$

${ }^{1}$ Ghrelin Research Project and ${ }^{2}$ Post-genome Project, Department of Experimental Therapeutics, ${ }^{3}$ Department of Clinical Trial Design and Management, and ${ }^{4}$ Department of Clinical Innovative Medicine, ${ }^{5}$ Translational Research Center, Kyoto University Hospital, Kyoto University School of Medicine, Kyoto 606-8507, Japan and ${ }^{6}$ Department of Biochemistry, National Cardiovascular Center Research Institute, Osaka 565-8565, Japan

(Correspondence should be addressed to K Kangawa, Ghrelin Research Project, Department of Experimental Therapeutics, Translational Research Center, Kyoto University Hospital, 54 Shogoin-Kawaharacho, Sakyo-ku, Kyoto 606-8507, Japan; Email: kangawa@ri.ncvc.go.jp)

\begin{abstract}
Objective: It has been demonstrated that ghrelin plays a major role in the regulation of GH secretion and food intake. These actions make ghrelin a strong candidate for the treatment of GH deficiency, anorexia and cachexia. However, only preliminary studies have been performed to assess ghrelin administration in humans. In this study, we have conducted a double-blind, randomized, placebocontrolled trial to investigate the pharmacokinetics, safety, and endocrine and appetite effects of ghrelin in young healthy volunteers.

Design: Eighteen male volunteers were randomly assigned into three groups of six subjects: low- and high-dose ghrelin groups, who received intravenous injections of 1 and $5 \mu \mathrm{g} / \mathrm{kg}$ ghrelin (acylated form) respectively, and a placebo group who were injected with mannitol instead of ghrelin.

Results: Acylated ghrelin disappeared more rapidly from plasma than total ghrelin, with elimination half life $\left(t_{1 / 2}\right)$ of $9-13$ and $27-31$ min respectively. The number of subjects that experienced adverse effects did not significantly differ among the three groups, and all adverse effects were transient and well tolerated. Both the low and high doses of ghrelin strongly stimulated GH release (peak plasma concentration $\left(C_{\max , 0-90 \mathrm{~min}}\right): 124.2 \pm 63.9$ and $153.2 \pm 52.2 \mathrm{ng} / \mathrm{ml}$ for 1 and $5 \mu \mathrm{g} / \mathrm{kg}$ ghrelin respectively). Slight alterations of blood glucose and insulin levels after the injection were observed. Although not statistically significant, ghrelin administration tended to increase hunger sensation in a dose-dependent manner.

Conclusions: These results suggest that ghrelin is safe, and that clinical trials may be started to assess the usefulness of ghrelin for the treatment of disorders related to GH secretion and appetite.
\end{abstract}

European Journal of Endocrinology $150447-455$

\section{Introduction}

Ghrelin is a peptide hormone which was discovered in 1999 and is an endogenous ligand for the growth hormone (GH)-secretagogue receptor (GHS-R) (1). Ghrelin consists of 28 amino acids and contains a unique fatty acid modification, $n$-octanoylation, at Ser 3 . This acylation is essential for most of ghrelin's biological activities, although unacylated ghrelin has been recently reported to exert biological activities on cell proliferation $(2,3)$. Ghrelin is mainly produced in the stomach and circulates in the blood at a considerable plasma concentration. Expression of ghrelin is also detectable in the hypothalamus, intestine, pituitary, placenta and other tissues $(1,4-6)$. In addition, GHS-R expression has been demonstrated in several tissues other than the hypothalamus and pituitary (6-8).
Reflecting the wide expression patterns of both the ligand and the receptor, ghrelin is now known to play a role in a number of different physiological processes. For example, ghrelin increases GH secretion, feeding and body weight when administered centrally or peripherally to rodents $(1,9-11)$. Additionally, in humans, intravenous administration of ghrelin increases GH secretion and food intake (12-18). Thus, ghrelin elicits multiple effects in both the brain and peripheral tissues $(19,20)$.

These unique effects of ghrelin and GHS will be invaluable for the development of novel treatments and disease diagnostics $(21-23)$. Clinical trials have already been performed to assess the utility of GHS for the treatment of short stature (24), GH deficiency $(24,25)$, obesity (26) and catabolic conditions (27). However, only preliminary studies have been performed 
to assess the possible benefits of ghrelin administration to humans $(12-18,28-31)$. Indeed, these studies include only one non-randomized phase I clinical trial (15). In this study, we performed a phase I/II trial to investigate the pharmacokinetics, safety and efficacy of ghrelin with regards to induction of hormone secretion and appetite in healthy volunteers.

\section{Materials and methods}

\section{Healthy volunteers}

Eighteen male volunteers between 21 and 25 years old participated in our phase I/II study, which was conducted at Kyoto University Hospital (Kyoto, Japan). The volunteers were judged to be healthy by standard clinical and laboratory investigations including chest X-ray, 12-lead electrocardiogram, prick allergen testing and blood pressure responses to postural changes. In addition, they were not suffering from any medical diseases or receiving medical treatment and had no past history of malignant disorders. They were randomly assigned to three groups: low- and high-dose ghrelin groups and a placebo group (see below). The baseline characteristics of each group of volunteers are summarized in Table 1. There were no significant differences in age, body mass index (BMI) or other parameters between the three groups. The study protocol was approved by the ethics committee on human research at the Kyoto University Graduate School of Medicine (project proposal number 400), and the studies were performed according to Good Clinical Practice (GCP) standards. Written informed consent was obtained from the volunteers prior to enrolment.

\section{Study design}

The study was randomized, double-blinded and placebo-controlled. Over a week-long screening period, eligible volunteers received either a bolus intravenous injection of ghrelin $(1 \mu \mathrm{g} / \mathrm{kg}$ for the low-dose group or $5 \mu \mathrm{g} / \mathrm{kg}$ for the high-dose group) or a placebo injection (3.75\% D-mannitol). Treatment assignments were randomized centrally to a 1:1:1 ratio, in blocks of three.
The randomization code was generated by a statistician from the Department of Clinical Trial Design and Management and was maintained there until all data had been collected and the study was unblinded. Neither the investigators nor the volunteers were aware of the treatment assignments in the study.

\section{Study drug}

Human ghrelin was synthesized as previously described $(1,12,15,17)$. The acylated peptide was dissolved in $3.75 \%$ D-mannitol to yield a final concentration of 40 or $400 \mu \mathrm{g} / \mathrm{ml}$. These solutions were then filtered and stored at $-20{ }^{\circ} \mathrm{C}$ in sterile vials. Examinations conducted by the Japan Food Research Laboratories (Tokyo, Japan) found no traces of endotoxin in the ghrelin solutions, and a pyogen test based on the Japanese Pharmacopoeia was negative.

\section{Assessment of safety}

Overall safety was assessed on the following day and at 8 days post-infusion. At all study visits, vital signs (pulse rate and blood pressure), haematology, blood chemistry and urinalysis were measured. All volunteers were hospitalized during the night of drug administration.

\section{Measurement of plasma ghrelin, GH, insulin-like growth factor-I (IGF-I), glucose and insulin concentrations}

On infusion days, subjects were fasted overnight and had two intravenous cannulae (one for infusion and one for blood sampling) implanted at $0900 \mathrm{~h}$ $(t=-45 \mathrm{~min})$. Blood samples for hormone and glucose analyses were drawn from an indwelling catheter fixed in a forearm vein at $-15,0,15,30,45,60$ and $90 \mathrm{~min}$ after drug administration. Pulse rate and blood pressure readings were taken at every blood drawing. NRIAs and C-RIAs (radioimmunoassay (RIA) for the ghrelin $\mathrm{N}$ - and C-terminals, respectively) for plasma ghrelin were performed using anti-human ghrelin-(1$11)$ and -(13-28) sera respectively, as described previously $(32,33)$. The anti-human ghrelin- $(1-11)$

Table 1 Summary of volunteer baseline characteristics (means \pm S.D.).

\begin{tabular}{|c|c|c|c|}
\hline Variable & Placebo $(n=6)$ & $1.0 \mu \mathrm{g} / \mathrm{kg}$ ghrelin $(n=6)$ & $5.0 \mu \mathrm{g} / \mathbf{k g}$ ghrelin $(n=6)$ \\
\hline Age (years) & $23.3 \pm 1.5$ & $22.8 \pm 1.7$ & $22.0 \pm 0.0$ \\
\hline BMI $\left(\mathrm{kg} / \mathrm{m}^{2}\right)$ & $20.1 \pm 1.9$ & $22.0 \pm 2.0$ & $20.9 \pm 0.8$ \\
\hline Weight $(\mathrm{kg})$ & $62.8 \pm 6.0$ & $64.0 \pm 8.4$ & $63.2 \pm 5.7$ \\
\hline Serum GH (ng/ml) & $6.2 \pm 6.2$ & $0.8 \pm 1.0$ & $1.9 \pm 3.9$ \\
\hline Serum IGF-I (ng/ml) & $275.7 \pm 67.6$ & $262.8 \pm 98.5$ & $287.8 \pm 62.3$ \\
\hline Plasma glucose (mg/dl) & $82.8 \pm 3.4$ & $84.8 \pm 7.1$ & $78.7 \pm 6.6$ \\
\hline Serum insulin $(\mathrm{U} / \mathrm{ml})$ & $4.1 \pm 2.2$ & $3.4 \pm 2.0$ & $4.3 \pm 1.2$ \\
\hline Plasma total ghrelin (fmol/ml) & $221.6 \pm 46.3$ & $149.2 \pm 66.8$ & $188.0 \pm 62.6$ \\
\hline Plasma active ghrelin (fmol/ml) & $18.3 \pm 5.4$ & $12.0 \pm 5.3$ & $20.7 \pm 10.1^{*}$ \\
\hline
\end{tabular}

${ }^{*} n=5$; the active ghrelin level of one patient was eliminated because the sample was stored improperly. 
antiserum specifically recognizes the n-octanoylated portion of ghrelin and does not recognize des- $n$-octanoylated ghrelin, while the anti-human ghrelin-(1328) antiserum recognizes both n-octanoyl-modified and des- $n$-octanoylated ghrelin equally. Thus, by using both assays we were able to measure the total ghrelin plasma concentration and the concentration of the active form only. Serum GH, IGF-I and insulin were measured by immunoradiometric assay (IRMA) (FALCO Biosystems Ltd, Kyoto, Japan). IGF-I was measured before infusion, and also 1 and 8 days after the infusion.

\section{Assessment of hunger sensation}

Visual analogue scales rating hunger (possible scores $0-10 \mathrm{~cm}$ ) were completed pre-infusion at $-15 \mathrm{~min}$, at infusion (0) and 15, 30, 45, 60 and $90 \mathrm{~min}$ after the administration of the study drug $(34,35)$. Positions on the scale were measured in centimetres and millimetres by an investigator who was unaware of the treatment groups. The change $(\Delta)$ in the visual analogue score at time $t$ was calculated by subtracting the visual analogue score at $0 \mathrm{~min}$ from the score at time $t$ in the same subject.

\section{Pharmacokinetic and statistical evaluations}

The pharmacokinetic evaluation for ghrelin was performed using the one-compartment model (36). The peak plasma concentration $\left(C_{\text {max }}\right)$ was calculated with PK Solutions version 2 (Summit Research Services, CO, USA) and S-PLUS Version 4.0 (Mathematical Systems Inc., Japan). The area under the curve (AUC) for the

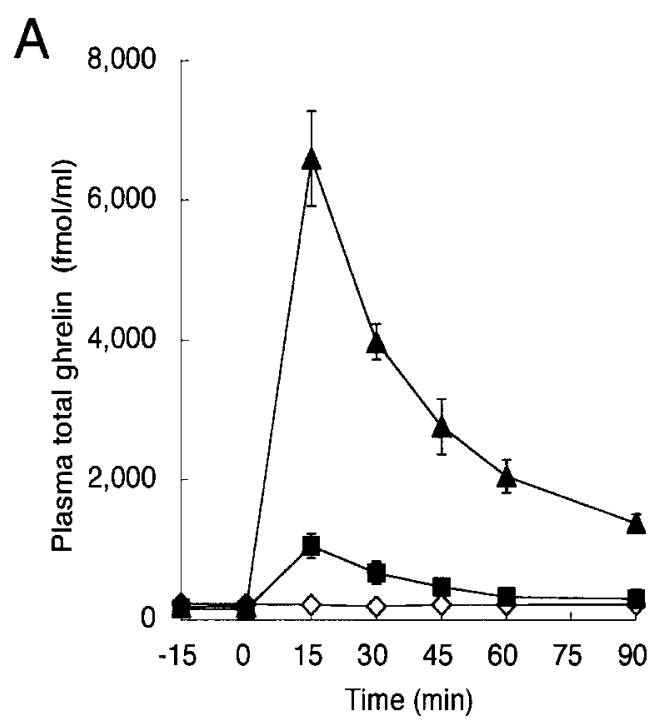

entire 90 min blood-sampling period was calculated by the trapezoidal method. The $t_{1 / 2}$ was calculated as $\ln$ $2 / z$, where $z$ is the terminal elimination rate constant. Pharmacokinetic parameters were analysed descriptively with the calculation of geometric means and 95\% confidence intervals (CI). Comparisons between groups administered with different study drugs were performed using the Wilcoxon rank sum test with the Bonferroni correction. Other statistical analyses were performed with SAS version 8 (SAS Institute Inc., Cary, NC, USA). A two-tailed $P$ value was used, with the required level of significance being $P<0.05$.

\section{Results}

\section{Pharmacokinetics}

Mean plasma concentration-vs-time profiles of ghrelin after administration are shown in Fig. 1. Descriptive statistics of the pharmacokinetic parameters of ghrelin are summarized in Table 2. After administration of 1 and $5 \mu \mathrm{g} / \mathrm{kg}$ ghrelin, total plasma ghrelin concentrations reached 1058.7 and $6597.9 \mathrm{fmol} / \mathrm{ml}$ respectively, and had an elimination $t_{1 / 2}$ of $27-31 \mathrm{~min}$. Active ghrelin at $15 \mathrm{~min}$ accounted for $42.2-52.3 \%$ of total ghrelin, and displayed a $t_{1 / 2}$ of $9-13 \mathrm{~min}$, roughly one-third that of total ghrelin. The active ghrelin levels of one patient administered with $5 \mu \mathrm{g} / \mathrm{kg}$ ghrelin were eliminated from the analysis because his samples were stored improperly.

\section{Assessment of safety}

Several adverse events were reported by ghrelininjected subjects (Table 3), but all of these complaints

\section{B}

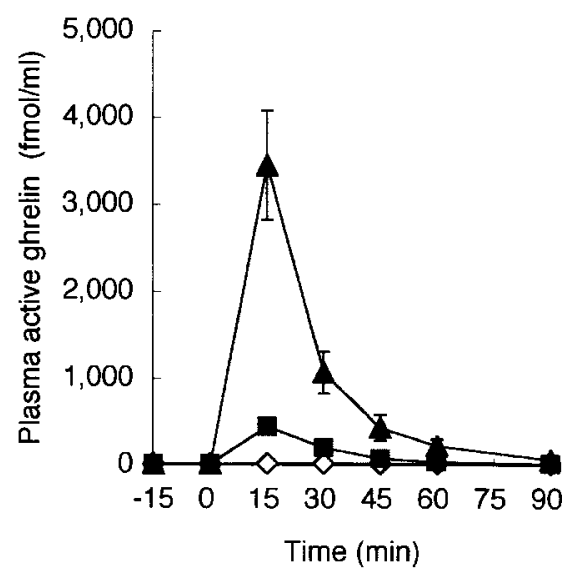

Figure 1 Pharmacokinetics of intravenous bolus administration of ghrelin. Plasma ghrelin concentrations were measured by $\mathrm{C}$ - and $\mathrm{N}$-RIA for total (A) and active ghrelin (B) respectively. $\boldsymbol{\Lambda}, 5 \mu \mathrm{g} / \mathrm{kg}$ ghrelin; $\mathbf{\square}, 1 \mu \mathrm{g} / \mathrm{kg}$ ghrelin; $\square$, placebo. All values are expressed as means $\pm 95 \% \mathrm{Cl}(n=6(\mathrm{~A})$ and $n=5(\mathrm{~B}))$. 
Table 2 Pharmacokinetic parameters of intravenous bolus administration of ghrelin. Results are given as means with $95 \%$ confidence intervals in parentheses.

\begin{tabular}{|c|c|c|c|c|}
\hline & $C_{\max , 0-90 \min }(\mathrm{fmol} / \mathrm{ml})$ & AUC $_{0-90 \min }\left(10^{3} \mathrm{fmol} \mathrm{min} / \mathrm{ml}\right)$ & $\mathbf{A U C}_{0-90 \mathrm{~min}}\left(10^{3} \mathrm{fmol} \mathrm{min} / \mathrm{ml}\right)^{*}$ & $\boldsymbol{t}_{1 / 2}(\min )$ \\
\hline \multicolumn{5}{|l|}{ Total ghrelin } \\
\hline Placebo $(n=6)$ & $230.7(187.8,273.5)$ & $18.92(16.51,21.34)$ & & \\
\hline $1.0 \mu \mathrm{g} / \mathrm{kg}$ ghrelin $(n=6)$ & $1058.7(882.6,1234.8)$ & $45.91(35.64,56.17)$ & $54.6(43.80,65.41)$ & $31.33(20.49,42.18)$ \\
\hline $5.0 \mu \mathrm{g} / \mathrm{kg}$ ghrelin $(n=6)$ & $6597.9(5919.0,7276.6)$ & $268.51(244.10,292.91)$ & $327.87(299.03,356.71)$ & $26.92(24.65,29.19)$ \\
\hline \multicolumn{5}{|l|}{ Active ghrelin } \\
\hline Placebo $(n=6)$ & $23.8(19.4,28.2)$ & $1.91(1.58,2.23)$ & & \\
\hline $1.0 \mu \mathrm{g} / \mathrm{kg}$ ghrelin $(n=6)$ & $447.2(387.0,507.5)$ & $12.27(10.27,14.26)$ & $18.92(16.70,21.14)$ & $12.90(8.97,16.83)$ \\
\hline $5.0 \mu \mathrm{g} / \mathrm{kg}$ ghrelin $(n=5)$ & $3454.0(2714.5,4194.6)$ & $80.67(66.74,94.59)$ & $143.68(107.99,179.36)$ & $9.56(7.37,11.74)$ \\
\hline
\end{tabular}

* $A \cup C_{0-90 ~ m i n}$ in one-compartment model.

Table 3 Adverse events.

\begin{tabular}{|c|c|c|c|}
\hline Adverse event & Placebo $(n=6)$ & $\begin{array}{c}1.0 \mu \mathbf{g} / \mathbf{k g} \\
\text { ghrelin }(n=6)\end{array}$ & $\begin{array}{c}5.0 \mu \mathbf{g} / \mathbf{k g} \\
\text { ghrelin }(n=6)\end{array}$ \\
\hline Abdominal discomfort & 0 & 1 & 0 \\
\hline Abdominal pain & 0 & 0 & 1 \\
\hline Diarrhoea & 0 & 0 & 1 \\
\hline Malaise & 1 & 0 & 0 \\
\hline Fever & 0 & 0 & 1 \\
\hline Glucosuria & 1 & 1 & 0 \\
\hline Leukocytosis & 0 & 0 & 1 \\
\hline Proteinuria & 1 & 0 & 0 \\
\hline Hypoesthesia & 1 & 0 & 0 \\
\hline Somnolence & 0 & 2 & 0 \\
\hline Throat redness & 0 & 0 & 1 \\
\hline Hyperhidrosis & 0 & 0 & 1 \\
\hline Flushing & 0 & 1 & 1 \\
\hline Total & 4 & 5 & 7 \\
\hline Number of subjects & 3 & 2 & 2 \\
\hline (Incidence, $95 \% \mathrm{Cl}$ ) & $(0.50,0.12 \sim 0.88)$ & $(0.33,0.04 \sim 0.78)$ & $(0.33,0.04 \sim 0.78)$ \\
\hline
\end{tabular}

were transient and well tolerated. One subject administered with $1 \mu \mathrm{g} / \mathrm{kg}$ ghrelin experienced mild abdominal discomfort and a flushed sensation for a few minutes; another subject injected with $5 \mu \mathrm{g} / \mathrm{kg}$ ghrelin indicated a flushed sensation and a marked episode of perspiration in the upper part of the trunk that lasted for nearly an hour. Two subjects injected with $1 \mu \mathrm{g} / \mathrm{kg}$ ghrelin experienced somnolence. One subject administered with $5 \mu \mathrm{g} / \mathrm{kg}$ ghrelin manifested fever, pharyngeal redness and diarrhoea with abdominal pain and leukocytosis; however, specialist infectious disease physicians and investigators diagnosed him as having acute bacterial enterocolitis that was unrelated to the medication. No significant changes in heart rate or blood pressure were recorded following the injections. Ghrelin did not significantly alter the clinical blood chemistries or complete blood count, to the best of our ability to detect. Although mild glucosuria was found in a low-dose ghrelin subject on the day after the injection, it disappeared after 1 week and was also found in a placebo subject; this subject also returned to normal after 1 week. Another placebo subject showed mild proteinuria on the day after the injection, but did show any abnormal urinalysis after 1 week. Since both subjects did not show glucosuria at the screening or 1 week after injection, they were judged to be healthy. Abnormal urinary findings were not found in high-dose subjects. In total, the number of subjects that experienced adverse effects was not significantly different among the three groups (Table 3).

\section{GH and IGF-I release}

The GH responses to ghrelin are shown in Fig. 2A and Table 4. Ghrelin strongly stimulated GH release. No significant difference between the low- and high-dose ghrelin groups was observed in the peak or AUC GH release, suggesting that a submaximal-dose ceiling effect occurs even at $1 \mu \mathrm{g} / \mathrm{kg}$ ghrelin in normal young males. Administration of ghrelin did not induce a significant increase in plasma IGF-I (Fig. 2B).

\section{Plasma glucose and serum insulin}

Ghrelin administration resulted in significantly higher plasma glucose levels $15 \mathrm{~min}$ after injection with either 1 or $5 \mu \mathrm{g} / \mathrm{kg}$ ghrelin, although no dose dependency was observed (Fig. 3A). At 90 min after injection of $5 \mu \mathrm{g} / \mathrm{kg}$ ghrelin, plasma insulin demonstrated a statistically significant decrease (Fig. 3B). No significant 
A

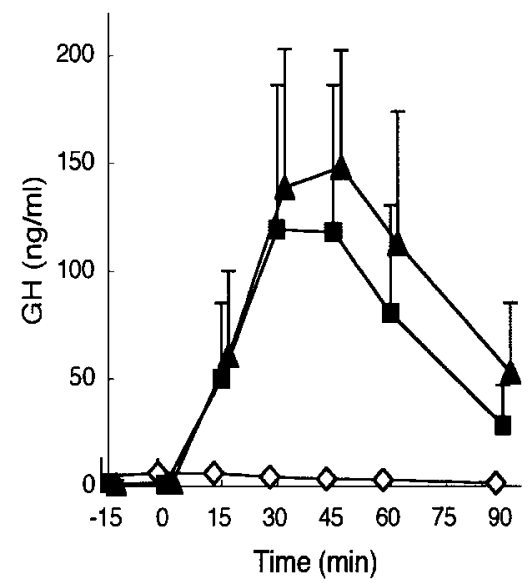

$\mathrm{B}$

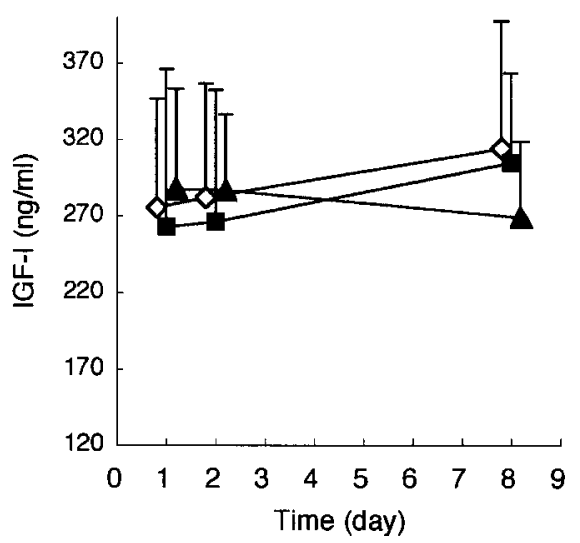

Figure 2 Serum GH (A) and IGF-I (B) levels following ghrelin administration. $\mathbf{\Lambda}, 5 \mu \mathrm{g} / \mathrm{kg}$ ghrelin; $\mathbf{\square}, 1 \mu \mathrm{g} / \mathrm{kg}$ ghrelin; $\diamond$, placebo. All values are expressed as means \pm S.D. $(n=6)$.

Table $4 \mathrm{GH}$, glucose and insulin responses to ghrelin administration (means \pm S.D.).

\begin{tabular}{|c|c|c|c|c|}
\hline & \multicolumn{2}{|c|}{ GH (ng/ml) } & \multicolumn{2}{|c|}{$\Delta \mathrm{AUC}_{0-90 \min }$} \\
\hline & $\mathrm{C}_{\max , 0-90 \text { min }^{*}}$ & $\mathrm{AUC}_{0-90 \min ^{\dagger}}{ }^{\dagger}$ & Glucose $(\mathrm{mg} / \mathrm{dl})^{\ddagger}$ & Insulin $(\mathrm{U} / \mathrm{ml})^{\S}$ \\
\hline $\begin{array}{l}\text { Placebo }(n=6) \\
1.0 \mu \mathrm{g} / \mathrm{kg} \text { ghrelin }(n=6) \\
5.0 \mu \mathrm{g} / \mathrm{kg} \text { ghrelin }(n=6)\end{array}$ & $\begin{array}{c}6.91 \pm 6.2 \\
124.2 \pm 63.9 \\
153.2 \pm 52.2\end{array}$ & $\begin{array}{c}344.2 \pm 307.1 \\
6547.3 \pm 3688.4 \\
8564.4 \pm 3630.6\end{array}$ & $\begin{array}{r}-82.5 \pm 138.4 \\
152.5 \pm 187.2 \\
166.25 \pm 455.8\end{array}$ & $\begin{array}{r}27.9 \pm 82.0 \\
-26.5 \pm 54.5 \\
-86.3 \pm 81.4\end{array}$ \\
\hline
\end{tabular}

${ }^{*} P=0.005$ : placebo vs $1.0 \mu \mathrm{g} / \mathrm{kg}$ ghrelin; placebo vs $5.0 \mu \mathrm{g} / \mathrm{kg}$ ghrelin.

${ }^{\dagger} P=0.005$ : placebo vs $1.0 \mu \mathrm{g} / \mathrm{kg}$ ghrelin; placebo vs $5.0 \mu \mathrm{g} / \mathrm{kg}$ ghrelin.

${ }^{\ddagger}$ Not significant (NS): placebo vs $1.0 \mu \mathrm{g} / \mathrm{kg}$ ghrelin; placebo vs $5.0 \mu \mathrm{g} / \mathrm{kg}$ ghrelin.

$\S \mathrm{NS}$ : placebo vs $1.0 \mu \mathrm{g} / \mathrm{kg}$ ghrelin; placebo vs $5.0 \mu \mathrm{g} / \mathrm{kg}$ ghrelin.

differences were observed in the $\triangle \mathrm{AUC}$ of glucose or insulin levels following ghrelin injection (Table 4).

\section{Hunger sensation}

Ghrelin administration tended to increase the hunger sensation in a dose-dependent manner, particularly within $45 \mathrm{~min}$ of injection (Fig. 4A). However, the difference between groups, based on evaluation by change in visual analogue score, did not reach statistically significance levels even at $15 \mathrm{~min}$ (Fig. 4B). In the placebo group, two of the six subjects did not show any change in hunger score. In contrast, all of the subjects in both the low- and high-dose ghrelin groups reported changes in their scores (data not shown).

\section{Discussion}

We performed a double-blind, randomized, placebocontrolled trial on 18 young healthy volunteers to investigate the pharmacokinetics, safety and efficacy of ghrelin in inducing hormone secretion and appetite.
Since the number of subjects studied may be too low to obtain thorough information about these effects of ghrelin, we adopted this study design to minimize the disadvantage or bias that is caused by the rather low number of subjects. This is the first report to simultaneously analyse the pharmacokinetics of both total and active ghrelin, and is a larger clinical trial of ghrelin administration than the only previous clinical trial (15). The total plasma ghrelin concentrations recorded at $15 \mathrm{~min}$ following administration of either 1 or $5 \mu \mathrm{g} / \mathrm{kg}$ ghrelin (3.2 and $20 \mathrm{ng} / \mathrm{ml}$ respectively) appeared to be comparable to those recorded during a previous trial which examined the administration of $10 \mu \mathrm{g} / \mathrm{kg}$ ghrelin $(\sim 60 \mathrm{ng} / \mathrm{ml})$ (15). Roughly $42.2-$ $52.3 \%$ of the total ghrelin at $15 \mathrm{~min}$ was active ghrelin. The elimination $t_{1 / 2}$ of total plasma ghrelin was 2731 min, nearly three times as long as that of active ghrelin, reflecting the rapid degradation of acylated active ghrelin in the plasma (33).

Several adverse effects were reported following ghrelin administration in our study, including abdominal discomfort, flushing, somnolence and hyperhidrosis (Table 3). Previous studies reported similar adverse 
A

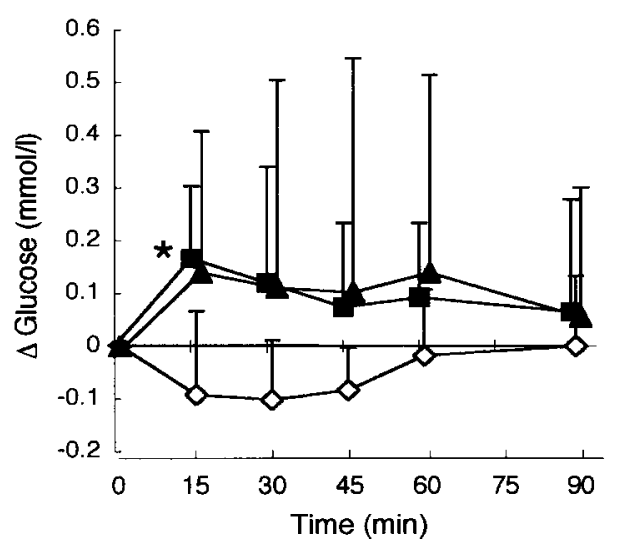

B

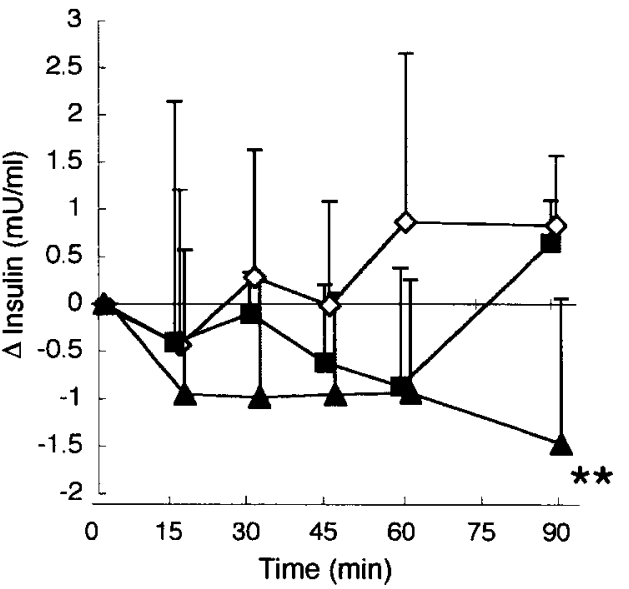

Figure 3 Changes in plasma glucose $(A)$ and serum insulin (B) concentrations after ghrelin administration. ${ }^{*} P<0.05,1 \mu \mathrm{g} / \mathrm{kg}$ ghrelin vs placebo. " $P<0.05,5 \mu \mathrm{g} / \mathrm{kg}$ ghrelin vs placebo or $1 \mu \mathrm{g} / \mathrm{kg}$ ghrelin. All values are expressed as means \pm S.D. $(n=6)$.

\section{A}

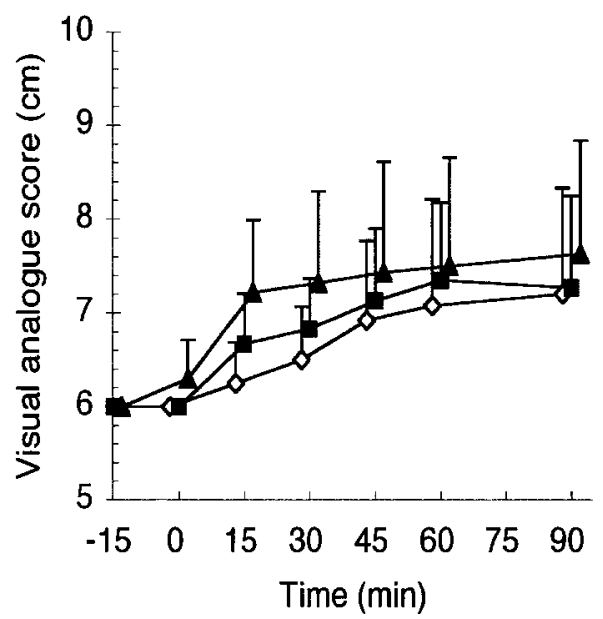

B

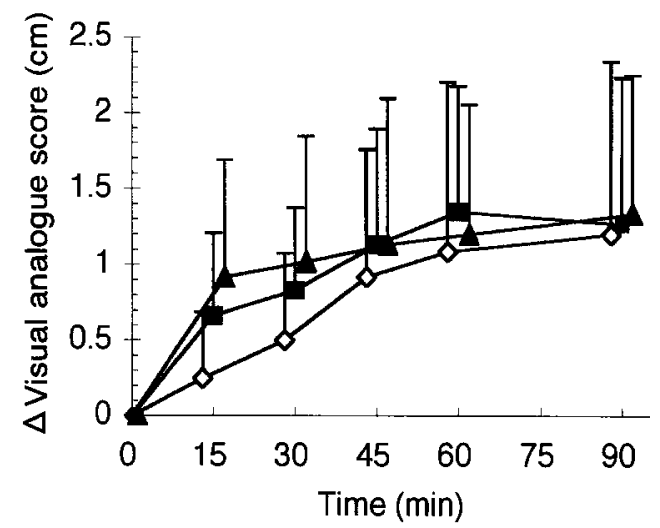

Figure 4 Changes in hunger scores following ghrelin administration. (A) Absolute visual analogue scores; (B) change in visual analogue scores. All values are expressed as means \pm S.D. $(n=6)$.

effects, but listed bowel movements and warm sensations instead of abdominal discomfort and flushing (Table 5). However, these are probably two different descriptions of the same phenomena. Because these adverse effects have been observed in multiple studies, it is likely that they are directly ghrelin related. All of these complaints, however, were transient and well tolerated. Ghrelin did not significantly alter clinical blood chemistries or complete blood count as far as we were able to discern.

In this study, $1 \mu \mathrm{g} / \mathrm{kg}$ of ghrelin appeared to result in a ceiling effect on the $\mathrm{GH}$ response in young men; $C_{\text {max }, 0-90 \min }$ of $\mathrm{GH}$ was $124.2 \pm 63.9 \mathrm{ng} / \mathrm{ml}$. This observation is in contrast to previous studies that were performed with the same size of groups (each group, $n=6$ ); the $1 \mu \mathrm{g} / \mathrm{kg}$ dose was observed to elicit a significantly lower response than the $5 \mu \mathrm{g} / \mathrm{kg}$ dose $(12,17)$. The GH response to the $5 \mu \mathrm{g} / \mathrm{kg}$ dose appears to be slightly higher than those of the previous studies; $C_{\text {max.0-90min }}$ of $\mathrm{GH}$ was $153.2 \pm 52.2 \mathrm{vs}$ $107.7 .0 \pm 23.9 \quad(12)$ or $109.8 \pm 26.2 \mathrm{ng} / \mathrm{ml} \quad$ (17) (Table 4). Although the reasons for this discrepancy are unclear, it may be explained by the fact that the volunteers in this study were younger than those in previous studies (22 vs. 31 years). In fact, age-related variations in GH response to ghrelin or GHS in humans have been reported $(30,37)$. To confirm this, it is necessary to carry out further studies using more subjects, including elderly people.

There are only three reports by two groups concerning the effects of ghrelin on glycaemia and insulin secretion in humans $(28,30,38)$. Broglio et al. (28) 
Table 5 Adverse events in previous studies administering ghrelin.

\begin{tabular}{lccll}
\hline References & No. of subjects & Sex $(\mathrm{M} / \mathrm{F})$ & Dose of ghrelin & Adverse events* \\
\hline Takaya et al. (12) & 6 & $\mathrm{M}$ & $1.0 \mathrm{or} 5.0 \mu \mathrm{g} / \mathrm{kg}$ & Bowel movement (2), warm sensation (2) \\
Arvat et al. (13) & 4 & $\mathrm{M}$ & $1.0 \mu \mathrm{g} / \mathrm{kg}$ & Hunger sensation (3) \\
Peino et al. (14) & 6 & $\mathrm{M}$ & $3.3 \mathrm{or} 6.6 \mu \mathrm{g} / \mathrm{kg}$ & Hyperhidrosis (2) \\
Nagaya et al. (15) & 6 & $\mathrm{M}$ & $10 \mu \mathrm{g} / \mathrm{kg}$ & Warm sensation (4), somnolence (4) \\
Arvat et al. (16) & 7 & $\mathrm{M}$ & $1.0 \mu \mathrm{g} / \mathrm{kg}$ & Hunger sensation (3) \\
Broglio et al. (28) & 11 & $\mathrm{M}$ & $1.0 \mu \mathrm{g} / \mathrm{kg}$ & Hunger sensation (6) \\
Micic et al. $(29)$ & 6 & $\mathrm{M}$ & $1.0 \mu \mathrm{g} / \mathrm{kg}$ & (No adverse events) \\
Broglio et al. (30) & 34 & $17 \mathrm{M} / 17 \mathrm{~F}$ & $1.0 \mu \mathrm{g} / \mathrm{kg}$ & Hunger sensation (12) \\
Weikel et al. (31) & 7 & $\mathrm{M}$ & $4 \times 50 \mu \mathrm{g}$ & (No adverse events) \\
Ukkola (39) & 8 & $4 \mathrm{M}, 4 \mathrm{~F}$ & $3.3 \mu \mathrm{g} / \mathrm{kg}$ & (No adverse events) \\
\hline
\end{tabular}

* Parentheses shows the number of subjects who experienced adverse events.

found that administration of 1 or $3.3 \mu \mathrm{g} / \mathrm{kg}$ ghrelin led to a transient inhibition of insulin secretion coupled with hyperglycaemic effects in normal male adults. However, in those studies, glucose remained persistently elevated from 15 to $165 \mathrm{~min}$, and absolute insulin levels were reduced from $30 \mathrm{~min}$ with a nadir at $45 \mathrm{~min}$. In addition, there were significant changes observed in glucose and insulin AUC. Arosio et al. (38) also found a significant increase in glucose concentrations at 15 and $30 \mathrm{~min}$, and a significant decrease $(41 \%$ decrease from the baseline) in insulin concentrations at $60 \mathrm{~min}$. Our results differ greatly from these previous studies, for we found that the ghrelin-induced glucose increase was much shorter and less pronounced, while the insulin decrease occurred later and to a lesser degree. Since the previous studies did not observe a significant change in insulin levels following ghrelin administration in young women, this insulin response may vary depending upon the type of group tested (30). Moreover, the effect of ghrelin on insulin secretion has been inconsistent in both human and animal models (39), as both inhibitory $(28,30,40)$ and stimulatory $(41-43)$ effects have been reported. Further studies are necessary to clarify the effect of ghrelin on glucose metabolism.

Ghrelin is the first circulating hormone demonstrated to stimulate appetite in man. Wren et al. (18) showed that a $17 \mathrm{ng} / \mathrm{kg}$ per min intravenous infusion of ghrelin for $270 \mathrm{~min}$ enhanced appetite and food intake in humans. The total amount of ghrelin infused in this study was $4.5 \mu \mathrm{g} / \mathrm{kg}$. Similarly, in this study, ghrelin administration tended to increase the hunger sensation in a dose-dependent manner, particularly in the early phase after injection, although the difference between groups did not reach statistically significant levels. In addition, while two of the six subjects in the placebo group did not show any change in hunger score, all of the subjects in both the low- and high-dose groups reported increases in hunger. To confirm this orexigenic effect of ghrelin, a study using larger-sized groups or a cross-over study will be necessary. Although Weikel et al. (31) reported that the subjects in their study did not feel a change in appetite after $4 \times 0.66 \mu \mathrm{g} / \mathrm{kg}$ of ghrelin administered hourly as intravenous boluses, that dose may have been too low to stimulate appetite. Because tests for appetite are subjective and variable among subjects, only double-blind tests such as this study may yield reliable findings.

In summary, we have confirmed the safety and hormonal effects of ghrelin in a randomized, double-blind test. No serious adverse effects were found. Ghrelin markedly stimulated GH release, slightly modulated blood glucose and insulin levels, and tended to increase the hunger sensation in a dose-dependent manner. These results suggest that ghrelin may have therapeutic and diagnostic potential in patients with disorders related to $\mathrm{GH}$ secretion and appetite.

\section{Acknowledgements}

We would like to thank Dr Hashida for preparing the drugs for this study, Dr Nakai for valuable advice regarding the measurement of visual analogue scores and Dr Ichiyama for consultation concerning infection of one subject and a critical review of laboratory tests. We would also like to thank Mr Asada, Mr Irikida, Mr Nakagawa, Mrs Sugiyama, Miss Sawai, Miss Nakatani and Miss Kouchi for their excellent secretarial assistance.

This study was supported by funds from the Ministry of Education, Science, Culture, Sports and Technology of Japan. There is no conflict of interest that would prejudice the impartiality of the research.

\section{References}

1 Kojima M, Hosoda H, Date Y, Nakazato M, Matsuo H \& Kangawa K. Ghrelin is a growth-hormone-releasing acylated peptide from stomach. Nature $1999 \mathbf{4 0 2} 656-660$.

2 Bedendi I, Alloatti G, Marcantoni A, Malan D, Catapano F, Ghe C et al. Cardiac effects of ghrelin and its endogenous derivatives desoctanoyl ghrelin and des-Gln(14)-ghrelin. European Journal of Pharmacology 2003 476 87-95.

3 Cassoni P. Papotti M. Ghe C. Catapano F, Sapino A. Graziani A et al. Identification, characterization, and biological activity of specific receptors for natural (ghrelin) and synthetic growth hormone secretagogues and analogs in human breast carcinomas 
and cell lines. Journal of Clinical Endocrinology and Metabolism $2001861738-1745$

4 Korbonits M, Bustin SA, Kojima M, Jordan S, Adams EF, Lowe DG et al. The expression of the growth hormone secretagogue receptor ligand ghrelin in normal and abnormal human pituitary and other neuroendocrine tumors. Journal of Clinical Endocrinology and Metabolism $200186881-887$.

5 Gualillo O, Caminos J, Blanco M, Garcia-Caballero T, Kojima M, Kangawa $\mathrm{K}$ et al. Ghrelin, a novel placental-derived hormone. Endocrinology 2001142 788-794.

6 Gnanapavan S, Kola B, Bustin SA, Morris DG, McGee P, Fairclough $\mathrm{P}$ et al. The tissue distribution of the mRNA of ghrelin and subtypes of its receptor, GHS-R, in humans. Journal of Clinical Endocrinology and Metabolism 200287 2988-2991.

7 Guan XM, Yu H, Palyha OC, McKee KK, Feighner SD, Sirinathsinghji DJ et al. Distribution of mRNA encoding the growth hormone secretagogue receptor in brain and peripheral tissues. Brain Research Molecular Brain Research 1997 48 23-29.

8 Papotti M, Ghe C, Cassoni P, Catapano F, Deghenghi R, Ghigo E et al. Growth hormone secretagogue binding sites in peripheral human tissues. Journal of Clinical Endocrinology and Metabolism 200085 3803-3807.

9 Tschop M, Smiley DL \& Heiman ML. Ghrelin induces adiposity in rodents. Nature $2000 \mathbf{4 0 7} 908-913$.

10 Wren AM, Small CJ, Ward HL, Murphy KG, Dakin CL, Taheri S et al. The novel hypothalamic peptide ghrelin stimulates food intake and growth hormone secretion. Endocrinology $2000 \mathbf{1 4 1}$ 4325-4328.

11 Nakazato M, Murakami N, Date Y, Kojima M, Matsuo H, Kangawa $\mathrm{K}$ et al. A role for ghrelin in the central regulation of feeding. Nature 2001409 194-198.

12 Takaya K, Ariyasu H, Kanamoto N, Iwakura H, Yoshimoto A, Harada M et al. Ghrelin strongly stimulates growth hormone release in humans. Journal of Clinical Endocrinology and Metabolism $2000854908-4911$.

13 Arvat E, Di Vito L, Broglio F, Papotti M, Muccioli G, Dieguez C et al. Preliminary evidence that ghrelin, the natural GH secretagogue (GHS)-receptor ligand, strongly stimulates GH secretion in humans. Journal of Endocrinological Investigation $2000 \quad 23$ 493-495.

14 Peino R, Baldelli R, Rodriguez-Garcia J, Rodriguez-Segade S, Kojima M, Kangawa K et al. Ghrelin-induced growth hormone secretion in humans. European Journal of Endocrinology 2000 $143 \mathrm{R} 11-\mathrm{R} 14$.

15 Nagaya N, Kojima M, Uematsu M, Yamagishi M, Hosoda H, Oya $\mathrm{H}$ et al. Hemodynamic and hormonal effects of human ghrelin in healthy volunteers. American Journal of Physiology Regulatory, Integrative and Comparative Physiology $20012 \mathbf{2 8 0}$ R1483-R1487.

16 Arvat E, Maccario M, Di Vito L, Broglio F, Benso A, Gottero C et al. Endocrine activities of ghrelin, a natural growth hormone secretagogue (GHS), in humans: comparison and interactions with hexarelin, a nonnatural peptidyl GHS, and GH-releasing hormone. Journal of Clinical Endocrinology and Metabolism 200186 $1169-1174$

17 Hataya Y, Akamizu T, Takaya K, Kanamoto N, Ariyasu H, Saijo M et al. A low dose of ghrelin stimulates growth hormone $(\mathrm{GH})$ release synergistically with $\mathrm{GH}-$ releasing hormone in humans. Journal of Clinical Endocrinology and Metabolism $2001 \mathbf{8 6}$ $4552-4555$

18 Wren AM, Seal LJ, Cohen MA, Brynes AE, Frost GS, Murphy KG et al. Ghrelin enhances appetite and increases food intake in humans. Journal of Clinical Endocrinology and Metabolism 2001 $865992-5995$

19 Muccioli G, Tschop M, Papotti M, Deghenghi R, Heiman M \& Ghigo E. Neuroendocrine and peripheral activities of ghrelin: implications in metabolism and obesity. European Journal of Pharmacology $2002440235-254$.
20 Horvath TL, Diano S, Sotonyi P, Heiman M \& Tschop M. Minireview: ghrelin and the regulation of energy balance - a hypothalamic perspective. Endocrinology 2001142 4163-4169.

21 Casanueva FF \& Dieguez C. Growth hormone secretagogues: physiological role and clinical utility. Trends in Endocrinology and Metabolism $19991030-38$.

22 Ghigo E, Arvat E \& Camanni F. Orally active growth hormone secretagogues: state of the art and clinical perspectives. Annals of Medicine 199830 159-168.

23 Petersenn S. Growth hormone secretagogues and ghrelin: an update on physiology and clinical relevance. Hormone Research 200258 (Suppl 3) 56-61.

24 Pihoker C, Badger TM, Reynolds GA \& Bowers CY. Treatment effects of intranasal growth hormone releasing peptide- 2 in children with short stature. Journal of Endocrinology 1997155 79-86.

25 Svensson J, Monson JP, Vetter T, Hansen TK, Savine R, Kann P et al. Oral administration of the growth hormone secretagogue NN703 in adult patients with growth hormone deficiency. Clinical Endocrinology (Oxford) $2003 \mathbf{5 8} 572-580$.

26 Svensson J, Lonn L, Jansson JO, Murphy G, Wyss D, Krupa D et al. Two-month treatment of obese subjects with the oral growth hormone $(\mathrm{GH})$ secretagogue MK-677 increases GH secretion, fat-free mass, and energy expenditure. Journal of Clinical Endocrinology and Metabolism $1998 \mathbf{8 3} 362-369$.

27 Murphy MG, Plunkett LM, Gertz BJ, He W, Wittreich J, Polvino WM et al. MK-677, an orally active growth hormone secretagogue, reverses diet-induced catabolism. Journal of Clinical Endocrinology and Metabolism 199883 320-325.

28 Broglio F, Arvat E, Benso A, Gottero C, Muccioli G, Papotti M et al. Ghrelin, a natural GH secretagogue produced by the stomach, induces hyperglycemia and reduces insulin secretion in humans. Journal of Clinical Endocrinology and Metabolism 2001 86 5083-5086.

29 Micic D, Macut D, Sumarac-Dumanovic M, Kendereski A, Popovic V, Deghenghi R et al. Ghrelin-induced GH secretion in normal subjects is partially resistant to homologous desensitization by GH-releasing peptide-6. European Journal of Endocrinology $2002147761-766$.

30 Broglio F, Benso A, Castiglioni C, Gottero C, Prodam F, Destefanis S et al. The endocrine response to ghrelin as a function of gender in humans in young and elderly subjects. Journal of Clinical Endocrinology and Metabolism $2003 \mathbf{8 8} 1537-1542$.

31 Weikel JC, Wichniak A, Ising M, Brunner H, Friess E, Held K et al. Ghrelin promotes slow-wave sleep in humans. American Journal of Physiology Endocrinology and Metabolism $2003 \mathbf{2 8 4}$ E407-E415.

32 Hosoda H, Kojima M, Matsuo H \& Kangawa K. Ghrelin and desacyl ghrelin: two major forms of rat ghrelin peptide in gastrointestinal tissue. Biochemical and Biophysical Research Communications 2000279 909-913.

33 Kanamoto N, Akamizu T, Hosoda H, Hataya Y, Ariyasu H, Takaya K et al. Substantial production of ghrelin by a human medullary thyroid carcinoma cell line. Journal of Clinical Endocrinology and Metabolism 200186 4984-4990.

34 Thompson DA \& Campbell RG. Hunger in humans induced by 2-deoxy-D-glucose: glucoprivic control of taste preference and food intake. Science $1977 \mathbf{1 9 8} 1065-1068$.

35 Nakai Y, Kinoshita F, Koh T, Tsujii S \& Tsukada T. Perception of hunger and satiety induced by 2-deoxy-D-glucose in anorexia nervosa and bulimia neervosa. International Journal of Eating Disorders $1987649-57$.

36 Gibaldi M \& Perrier D. Pharmacokinetics, 2nd edition, pp 1-44. New York: Marcel Dekker Inc., 1982.

37 Gottero C, Benso A, Prodam F, Broglio F, Castiglioni C, Bo M et al. Age-related variations of the $\mathrm{GH}$ response to $\mathrm{GH}$ secretagogues in humans. Journal of Endocrinological Investigation $20022542-43$

38 Arosio M, Ronchi CL, Gebbia C, Cappiello V, Beck-Peccoz P \& Peracchi M. Stimulatory effects of ghrelin on circulating 
somatostatin and pancreatic polypeptide levels. Journal of Clinical Endocrinology and Metabolism $2003 \mathbf{8 8}$ 701-704.

39 Ukkola O. Ghrelin and insulin metabolism. European Journal of Clinical Investigation 200333 183-185.

40 Egido EM, Rodriguez-Gallardo J, Silvestre RA \& Marco J. Inhibitory effect of ghrelin on insulin and pancreatic somatostatin secretion. European Journal of Endocrinology $2002146241-244$.

41 Adeghate E \& Ponery AS. Ghrelin stimulates insulin secretion from the pancreas of normal and diabetic rats. Journal of Neuroendocrinology $200214555-560$.

42 Lee HM, Wang G, Englander EW, Kojima M \& Greeley GH Jr. Ghrelin, a new gastrointestinal endocrine peptide that stimulates insulin secretion: enteric distribution, ontogeny, influence of endocrine, and dietary manipulations. Endocrinology $2002 \mathbf{1 4 3}$ 185-190.

43 Date Y, Nakazato M, Hashiguchi S, Dezaki K, Mondal MS, Hosoda $\mathrm{H}$ et al. Ghrelin is present in pancreatic alpha-cells of humans and rats and stimulates insulin secretion. Diabetes 200251 124-129.

Received 13 October 2003

Accepted 3 December 2003 